\title{
Recycling Agave Bagasse of the Tequila Industry
}

\author{
C. G. Iñiguez¹, C. J. J. Bernal2, M. W. Ramírez², N. J. Villalvazo² \\ ${ }^{1}$ Departamento de Madera, Celulosa y Papel, Centro Universitario de Ciencias Exactas e Ingenierías, \\ Universidad de Guadalajara, Guadalajara, México \\ ${ }^{2}$ Departamento de Ingeniería de Proyectos, Centro Universitario de Ciencias Exactas e Ingenierías, \\ Universidad de Guadalajara, Guadalajara, México \\ Email: giniguez@dmcyp.cucei.udg.mx
}

Received 23 February 2014; revised 23 March 2014; accepted 30 March 2014

Copyright (C) 2014 by authors and Scientific Research Publishing Inc.

This work is licensed under the Creative Commons Attribution International License (CC BY).

http://creativecommons.org/licenses/by/4.0/

(c) (i) Open Access

\section{Abstract}

This paper presents an overview of different handling systems and use of the agave bagasse. These systems have appeared from different research works always taking in account the environmental sustainability. It is mentioned that the agave bagasse can be used for animal feeding, for the elaboration of compound materials, as an element for agricultural and hydroponic vegetables cultivation purposes, and also as a means to treat biosolids, vinasses, and bagasses of slaughterhouses and tanneries.

\section{Keywords}

Agave Bagasse, Tequila Vinasses, Tequila

\section{Introduction}

Tequila production has contributed to the agricultural and industrial development in Mexico, especially in the State of Jalisco. In the last nine years, the agave consumption and tequila production have increased considerably. In 2003, the industrialization of the agave heads was of 412,900 tons, and by 2011 it was of 998,400 tons, with a decrease of $11.8 \%$ in 2012 (880,600 tons) and a maximum of 1,125,100 in 2008 [1]. Fortunately, this sudden growth of the tequila industry has not ignored the handling and disposal of two of the main by-products: agave bagasse and vinasses. With regard to vinasses, many actions are still to be taken due to its high pollution power: only few companies have successfully resolved their handling because of their financial capacity. The methods most commonly used to treat vinasses are the separation of settleable solids and the anaerobic digestion followed by aerated lagoons or activated sludge. In reference to the agave bagasse handling, the majority of the 
big and medium companies have chosen the composting process, as a resource for the disposal of vinasses, settleable solids or biosolids from the treatment plants. The objective of this paper is to highlight or provide with alternatives of handling and using the agave bagasse to give environmental sustainability to the tequila industry.

\section{Agave Bagasse}

The agave bagasse is the residual fibrous material remaining after the Agave tequilana Weber var. azul heads are shredded, cooked, milled and the sugars are water-extracted to produce tequila. The bagasse is primarily the rind and fibrovascular bundles dispersed throughout the interior of the agave head. Nowadays some tequila factories have upgraded their processes to obtain tequila, to smash only the agave heads so then with hot water extract the fermentable sugars, resulting in an agave bagasse with different characteristics than the first one. The bagasse is compounded of fiber and pith. The fiber is thick walled and long $(10-12 \mathrm{~cm})$. It represents about $40 \%$ of the total weight of the milled agave on a wet weight basis [2]. Bagasse is available all year in only two main regions of the tequila producing areas in Mexico: the Tequila region and the Jalisco Highlands. Tables 1-4 show some of the physical and chemical characteristics ofagave bagasse obtained from cooked agave heads.

\subsection{Agave Bagasse for Animal Feeding}

Because of its characteristics, the agave bagasse as it comes out of the tequila factory is difficult to be used for animal feed. The level of usefulness depends on the attack that it has in the rumination micro flora. The best mi-

Table 1. Chemical composition of dry agave bagasse (5\% water content).

\begin{tabular}{cc}
\hline Item & (\%) \\
\hline Cellulose & 43 \\
Lignin & 15 \\
Hemicellulose & 19 \\
Total nitrogen & 3 \\
Pectins & 1 \\
Fats & 1 \\
Reducing sugars & 5 \\
Ash & 6 \\
Others & 2 \\
\hline
\end{tabular}

Source: [16].

Table 2. Physical composition of the dry agave bagasse (5\% water content).

\begin{tabular}{cc}
\hline Texture & Not very rigid \\
\hline Color & Brown-yellow \\
Fiber length & $5-10 \mathrm{~cm}$ \\
Diameter & $0.3-0.4 \mathrm{~mm}$ \\
Water absorption & $6 \mathrm{~mL} \cdot \mathrm{g}^{-1}$ \\
\hline
\end{tabular}

Source: [16].

Table 3. Extracted sugar analysis (wet agave bagasse).

\begin{tabular}{cccc}
\hline Item & Reducing Sugars (\%, dry basis) & Fructose (\%, dry basis) & Glucose (\%, dry basis) \\
\hline Tequila factory 1 & 5 & 0.4 & 0.4 \\
Tequila factory 2 & 8 & 5 & 0.5 \\
Tequila factory 3 & 10 & 7 & 0.5 \\
Tequila factory 4 & 12 & & 0.5 \\
\hline
\end{tabular}

Source: [16]. 
Table 4. Free extracted sugars (dry agave bagasse).

\begin{tabular}{ccc}
\hline Item & Extraction $70^{\circ} \mathrm{C} 3 \mathrm{~h}(\%$, dry matter $)$ & Extraction $90^{\circ} \mathrm{C} 3 \mathrm{~h}(\%$, dry matter $)$ \\
\hline Fructose & 1.00 & 1.20 \\
Arabinose & 0.02 & 0.04 \\
Glucose & 0.02 & 0.02 \\
Galactose & 0.02 & 0.02 \\
\hline
\end{tabular}

Source: [16].

crobial use of cellulose and lignocellulosic agricultural by-products is limited by the close physical and chemical association between structural carbohydrates and lignin and the crystalline arrangement of the cellulose polymer in plant cell walls [3]-[5]. Lignin is the most important factor limiting degradation of cellulose by microorganisms [6]. However, to facilitate the optimal use of the bagasse for feeding animals, it can start by the physic separation of what has a low digestibility as the fiber and what has a higher digestibility as the pith. Figure 1 shows a piece of equipment used for that, and Table 5 shows the results of the effect of the screen mesh size on separation of agave bagasse from different tequila factories. It is seen that the amount of recovered pith depends on the manner in which agave heads were processed for fermentable sugar extraction. For example, there was a significant difference $(P<0.05)$ between the yield of recovered pith from the agave heads processed in "La Rojeña”, Sauza and Camichines tequila factories. In the La Rojeña tequila factory, the bagasse comes from cooked, shredded and pressed agave heads in mills to extract the sugars. In the Sauza factory, the bagasse comes from shredded agave heads before cooking and sugars extraction in pressing mills. In the Camichines tequila factory, the bagasse comes from shredded agave heads, subjected to a sugars extraction process using hot water and in the processing mills. The extracted juice is cooked in a later step. Table 6 shows the behavior of lambs when they were fed with 3 comparatives diets. Diet 1, or control diet, was basically formulated with a base of ground corn (79.3\%), ground alfalfa (15\%) and cane molasses (5\%). The remains were mineral elements. Diet 2 was mainly $63.3 \%$ of agave pith, and diet 3 of $63.3 \%$ of corn [7]. Note that in the table, the weight gain and the daily feed consumption were statistically the same $(P>0.05)$ among the diets based in the pith and the corn-based diet. Table 7 shows the results of a study in which a balanced diet based in agave bagasse pith was formulated. In this case, the animals average daily gain was $186 \mathrm{~g}$, a result which is very similar to the one reported in Table 6 with a difference in dry matter intake (783 vs. $1077 \mathrm{~g} /$ day) [7]. A better use of the agave bagasse pith for animals' feed implies that this should be eaten immediately to avoid its decomposition because of opportunist microorganisms. The pith silage can be an alternative conservation while not used. Silage is a conservation processes for forage based in a lactic fermentation of the grass that produces lactic acid and a decrease of the $\mathrm{pH}$ below 5 . It allows holding original grass nutritive qualities much better than the dry forage.

\subsection{Agave Bagasse for Composite Materials}

The agave bagasse can be used for the manufacturing of composite materials provided that the pith is removed, as this can be used for animal feeding. In 2001 Iñiguez et al. [7] prepared medium and high density boards samples with short and long agave bagasse fibers. These samples presented comparable properties to boards' prepared with fibers and wood particles. They were stronger in flexion tests than the ANSI standards (American National Standards Institute) for hard boards. Figure 2 shows board samples prepared with short and long agave bagasse fibers.

\subsection{Agave Bagasse as Substrate for Agricultural Purposes}

It results interesting to use agave bagasse as a substrate for agricultural purposes as long as the fiber is not completely degraded in the composting process. Iñiguez et al. [8], in a greenhouse test with tomatoes, found no significant statistics differences ( $\mathrm{p} \leq 0.5)$ when two substrates of agave bagasse compost and two commercial substrates were used (coconut coir and “cocopeat”) to evaluate the production and quality of tomatoes from the first to fifth cut after 55 days of transplantation (Figure 3). Martínez et al. [9] used three agave mezcalerobagasse compost (piling time: 0, 90 and 180 days) as organic substrate in tomatoes cultivation (Solanumlycopersicum L.). They reported that the fruit quality was not affected and the output was surpassed, when compared with coco powder substrate. With the 180 days pill-up bagasse the best output was obtained ( $3.5 \mathrm{~kg}$ per plant) and number 
Table 5. Effects of screen mesh size on separation of agave bagasse from different sources.

\begin{tabular}{cccccc}
\hline \multirow{2}{*}{ Tequila Factory } & $\begin{array}{c}\text { Agave bagasse processed } \\
(\mathrm{kg})\end{array}$ & \multicolumn{3}{c}{${\text { Screen opening size }(\mathrm{cm}) \text { screen }^{\mathrm{a}}}$} & Recovered pith (\%) \\
\cline { 3 - 5 } & 100 & 2.54 & 2 & 3 & $36.0^{\mathrm{a}}$ \\
La Rojeña & 100 & 2.54 & 2.54 & 1.90 & $56.0^{\mathrm{a}}$ \\
Sauza & 100 & 2.54 & 2.54 & 1.90 & $45.3^{\mathrm{a}}$ \\
Orendain & 100 & 2.54 & 2.54 & 1.90 & $43.5^{\mathrm{a}}$ \\
Viuda de Romero & 100 & 2.54 & 2.54 & 2.54 & $38.3^{\mathrm{a}}$ \\
Camichines & & &
\end{tabular}

${ }^{\mathrm{a}}$ Mean of five runs; ${ }^{\mathrm{b}}$ Mean of eight runs; Source: [7].

Table 6. Comparison of sheep performance fed diets based on corn (1), agave bagasse pith (2) and corn stubble (3).

\begin{tabular}{|c|c|c|c|c|}
\hline \multirow{2}{*}{ Item } & \multicolumn{3}{|c|}{ Diet } & \multirow[t]{2}{*}{$\mathrm{SEM}^{\mathrm{a}}$} \\
\hline & 1 & 2 & 3 & \\
\hline Average daily gain (g) & $179.0^{\mathrm{b}}$ & $96.4^{\mathrm{c}}$ & $72.1^{\mathrm{c}}$ & 14.826 \\
\hline Dry matter intake (g/day) & $783.0^{\mathrm{b}}$ & $774.0^{\mathrm{b}}$ & $772.0^{\mathrm{b}}$ & 12.339 \\
\hline Feed/gain & $4.4^{\mathrm{b}}$ & $8.32^{\mathrm{c}}$ & $11.12^{\mathrm{b}}$ & 0.926 \\
\hline
\end{tabular}

${ }^{\mathrm{a}}$ Standard error of the mean; ${ }^{\mathrm{b}, \mathrm{c}}$ Means in the same row with different superscripts differ $(\mathrm{P}<0.05)$; Source: [7].

Table 7. Sheep performance fed diet based on agave bagasse pith.

\begin{tabular}{ccc}
\hline Item & Value $^{\mathrm{a}}$ & SEM $^{\mathrm{b}}$ \\
\hline Average daily gain (g) & 186.0 & 12.617 \\
Dry matter intake (g/day) & 1.077 & 0.056 \\
Feed/gain & 5.87 & 0.417 \\
\hline
\end{tabular}

${ }^{\mathrm{a}}$ Represents the mean of five pens with three animals per pen; ${ }^{\mathrm{b}}$ Standard error of the mean; Source: [7].

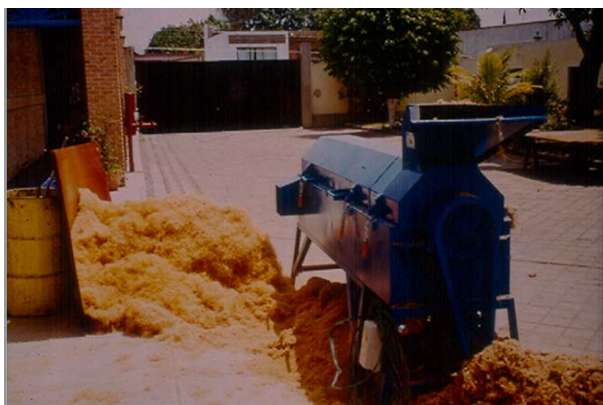

Figure 1. Equipment for the physical separation fiber/pith of the agave bagasse.

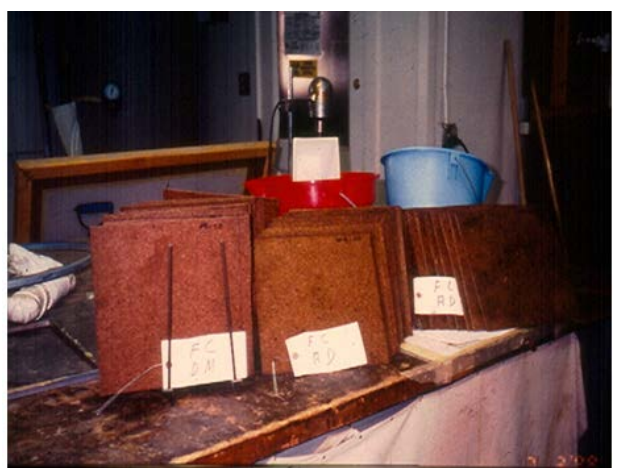

Figure 2. Board samples made with short and long agave bagasse fibers. 


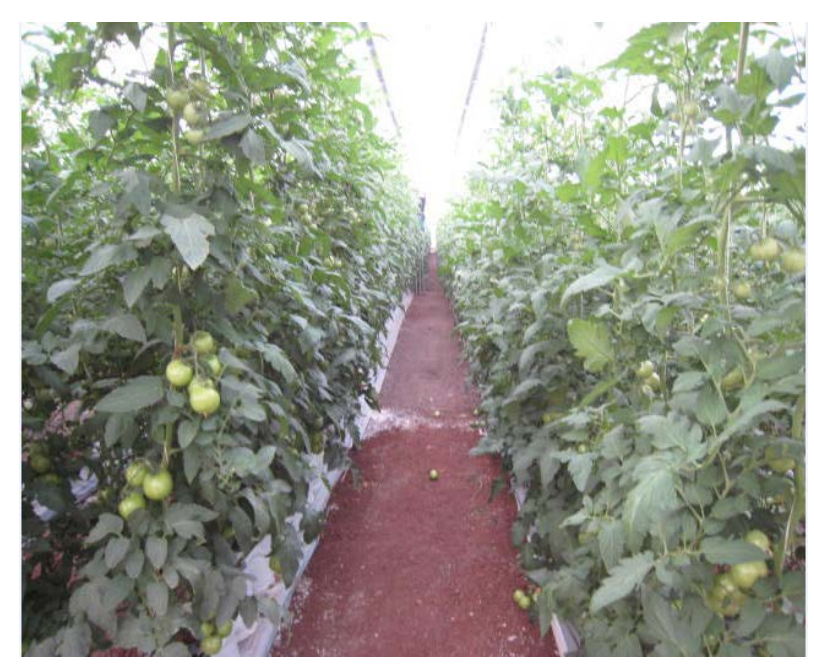

Figure 3. Tomato production using an agave bagasse substrate.

of commercial fruit (26.4 fruits per plant). Before planting in the field, Crespo et al. [10] used agave bagasse compost to adapt during 9 months (Figure 4), propagated agave seedling in vitro of approximately 16 months of age. The treatments were based in coco powder (PC) (Cocosnucifera), peat (T) (Sphagnum spp.) and agave bagasse compost (C). Those treatments consisted of: 1) $80 \% \mathrm{PC}+10 \% \mathrm{~T}+10 \% \mathrm{C}$; 2) $100 \% \mathrm{PC}$; 3) $100 \% \mathrm{~T}$; 4) $70 \%$ PC + 30\% C; 5) 50\% PC + 50\% C; 6) $30 \%$ PC + 70\% C; y 7) $100 \%$ C. The response of the agave plants to the different treatments was evaluated through the following morphologic parameters: Pine's diameter, (DPñ) and steam diameter (DTll); ratio DPñ/DTll; the longest leaf's length (LHj); longest leaf's width (AHj) (the widest section) and number of leaves ( $\mathrm{N} \mathrm{Hj}$ ). Three treatments that were prepared based on agave bagasse compost produced meaningful differences and highly meaningful in the morphologic parameters evaluated and widely surpassed the effects of the coco powder and the peat. Treatments with 30 and $50 \%$ compost produced a greater effect over the pine's and steam diameter, as well as over the number of leaves and their longitude; however, all the mixtures with compost increased the leaf's width. The obtained results reflect the possibility of substitute the commercial substrate with the compost substrates, particularly with the mixtures $30,50 \mathrm{y} 70 \%$. When this substitution was completed, abundant agave bagasse can be used, avoiding environmental pollution, and reducing production costs, as the bagasse compost can be locally elaborated. Rodríguez et al. [11] evaluated agave bagasse compost in comparison with commercial peat (Sunshine $\mathrm{Mix}_{3}$ y Berger $\mathrm{BM}_{2}$ ) for the production of tomatoes seedling(var. Hermosa) obtaining, with the agave bagasse compost, better height values, dry and fresh weight in the areal part and dry weight in the root.

\subsection{Agave Bagasse as a Tool for the Biosolids Treatment and Tequila Vinasses}

Rodríguez et al. [12] conducted a field study for the composting of the raw agave bagasse using biosolids from a tequila vinasses treatment plant to maintain the moisture of the process. Eight piles of 30 tons of bagasse each were put in composting. The piles 1 - 4 were moved each week to be ventilated and water or biosolids were added.1560 L of water were added to pile 1; and to piles $2-4,1560,3120$ and $4680 \mathrm{~L}$ of biosolids were added, respectively. Piles 5-8 were gradually added with the same amount of water or biosolids, with the exception that they were moved every two weeks. At the end of the 19 weeks composting period, the color, smell and texture of the material of the eight piles became similar to the garden soil. The ratio of processed bagasse $\mathrm{kg} / \mathrm{L}$ of water or biosolids added to the piles for the treatments 1 - 8 was of $1 / 0.728,1 / 0.676,1 / 1.04,1 / 1.56,1 / 0.52,1 / 0.364$, $1 / 0.572$ y $1 / 0.858$, respectively. If the last ratio is considered to add vinasses (as currently carried out) instead of biosolids to the agave bagasse compost piles, and if the 2011 CRT statistics [1] is considered regarding the bagasse and vinasses production, it is therefore concluded thatthe bagasse composting process could only treat $59.6 \%$ of the vinasse generated during the tequila production; so, $40.4 \%$ would require of another handling system. The obtained compost is used to enhance the physical and chemical soil structure in the agave plantations. Figure 5 shows a composting plant where the bagasse piles are used for the final disposal of the tequilavinasse. Iñiguez et al. [13] used the agave bagasse as a final disposal of the tequila vinasse. To do that, they put four 


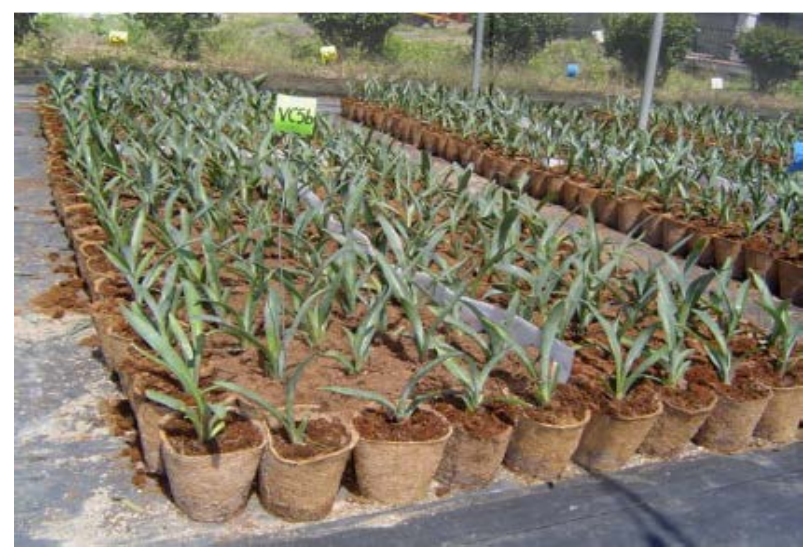

Figure 4. Use of an agavebagasse compost for the adaptation during 9 months of agave seedlingbefore planting in the field.

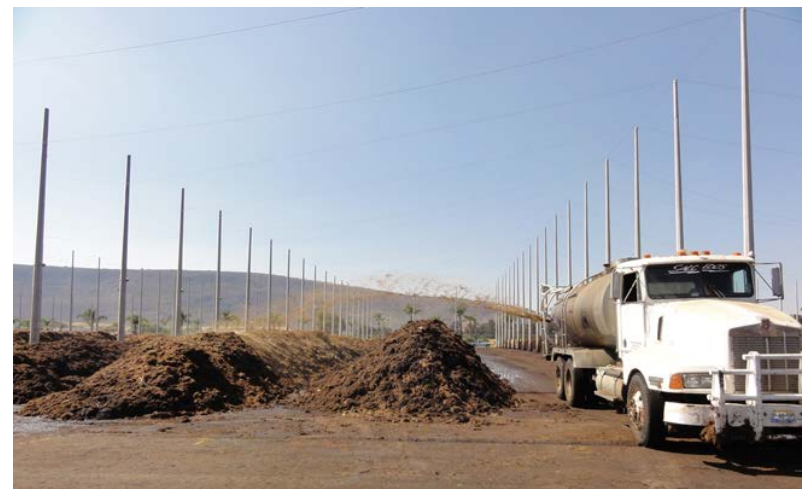

Figure 5. Composting plant where the bagasse piles are used for final disposal of the tequilavinasses.

bagasse piles in composting processand, during the process, two of them were irrigated with vinasses and the other two with water. The latter, at the beginning of the composting were added with urea to adjust the C:N ratio to 25:1. The test period for the piles with urea was of 228 days and during this time, $0.912 \mathrm{~L}$ of vinasses were added per kg of wet bagasse. The test period for the piles without urea was of 242 days and during this time, $0.55 \mathrm{~L}$ of vinasses were added per kg of wet bagasse. This showed that when the C:N ratio was initially adjusted to the recommended for good composting, the microbial activity was accelerated and a major water loss was noted, which enables the addition of more vinasses and resolves in a better way the final disposal. The obtained compost had similar characteristics to the garden soil without problems of phytotoxicity at the moment to be evaluated with cucumber seeds.

\subsection{Agave Bagasse as a Disposal Tool of Slaughterhouses and Tanneries Waste}

Agave bagasse was used as an alternative to stabilize the tannery residuals (hair and flesh material) through composting [14]. Two wood cells of $2.5 \mathrm{~m}$ wide by $2.5 \mathrm{~m}$ long and $1.5 \mathrm{~m}$ high were used alternating with tannery residuals and agave bagasse layers to a height of approximately $0.7 \mathrm{~m}$ with the result of achieving one ton of thread material in each cell. The biodegradation process of the thread material was followed by the regular measurement of the temperature changes. At the end of 154 days of thermophile degradation, the thread material was totally decomposed, having as a result a blackish product, with odor and texture similar to garden soil. There was a total loss of dry material of $67.3 \%$ in average for the two piles considering the initial and final weight of the ingredients. From the research, it was concluded that the biodegradation process by layers might convey a technicaland economically viable alternative to help the tannery industry in handling and final disposal of thread materials, obtaining a product with agronomic potential. Iñiguez y Vaca [15] researched the effective 


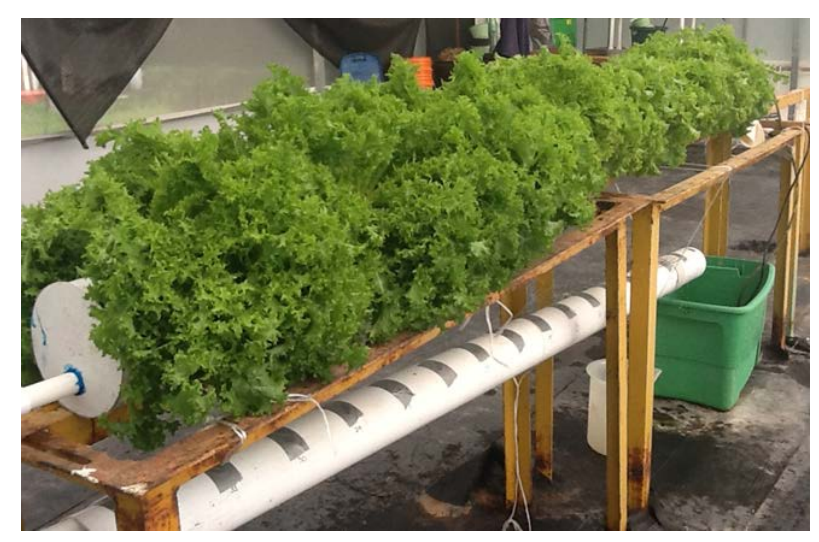

Figure 6. Italian lettuce cultivation with BAPEN hydroponic system.

ness of composting swine large intestines and wet agave bagasse using a layering method. It consisted of placing alternate layers of $150 \mathrm{~kg}$ of wet agave bagasse and $100 \mathrm{~kg}$ of pig intestines. The pile formed was moved every week to facilitate the ventilation and the water addition. After 102 composting days, the product turned dark brown with a smell of soil. After that, these trials were conducted in field conditions showing no problem.

\subsection{Agave Bagasse as a Substrate in Vegetable Hydroponics Cultivations}

There are 6 basic types of hydroponic systems: wick, water culture, ebb and flow (flood and Drain), drip (recovery and non-recovery), N.F.T. (Nutrient Film Technique) and aeroponics. There are hundreds of variations on these basic types of systems, but all hydroponic methods are a variation (or combination) of these six. One of these variations can be the so called system BAPEN, which consists of packing a substrate called BAGACOMCO PIT in a system of "bolis" (horizontal grow bags) to avoid the substrate dispersion and water evaporation. The "boli" is put in a PVC gutter provided with a thin bed of gravel to facilitate the recirculation of a nutritive area from a deposit (with a submerged pump) to a gutter and from here to the container by gravity (Figure 1). Italian lettuce seedling was grown in four different experiments, long lettuce (Latuca sativa), radish (Raphanussativus) and chard (Beta vulgaris var. Cicla). As an example, Figure 6 shows the results of the cultivation of Italian lettuce after 45 days in the development after the transplant. The average weight for plant (from 18) was of $217.5 \mathrm{~g}$ in comparison with $112.5 \mathrm{~g}$ of lettuce in the market.

\section{Conclusion}

Up to now, the agave bagasse has been used in the treatment of vinasses and final disposal of biosolids in the vinasses treatment plants. However, there is enough bibliographical information so the agave bagasse is used commercially as a substrate for the germination of different seeds, as well as for the development of seedling and mainly for the tomatoes production. On the other hand, due to the constant increase of fuels, tequila producers have been seriously considering to use agave bagasse for the generation of energy to support their own necessities.

\section{References}

[1] Consejo Regulador del Tequila (CRT) (2012) www.crt.org.mx

[2] Cedeño, C.M. (1995) Tequila Production. Critical Reviews in Biotechnology, 15, 1-11. http://dx.doi.org/10.3109/07388559509150529

[3] Morris, E.J. and Bacon, J.S.D. (1977) The Fate of Acetyl Groups and Sugar Components during the Digestion of Grass Cell Walls in Sheep. Journal of Agricultural Science, 89, 327-340. http://dx.doi.org/10.1017/S0021859600028252

[4] Hartley, R.D. and Jones, E.C. (1978) Effects of Aqueous Ammonia and Other Alkalis on the in Vitro Digestibility Barley Straw. Journal of the Science of Food and Agriculture, 29, 92-98. http://dx.doi.org/10.1002/jsfa.2740290204

[5] Scalbert, A., Monties, B., Lallemand, J.Y., Guittet, E. and Rolando, C. (1985) Ether Linkages between Phenolic Acids and Lignin Fractions from Wheat Straw. Phytochemistry, 24, 1359-1362. 
http://dx.doi.org/10.1016/S0031-9422(00)81133-4

[6] Gould, J.M. (1984) Studies on the Mechanism of Alkaline Peroxide Delignification of Agricultural Residues. Biotechnology and Bioengineering, 27, 225-231. http://dx.doi.org/10.1002/bit.260270303

[7] Iñiguez, C.G., Lange, E.S. and Rowell, M.R. (2001) Utilization of by Products from the Tequila Industry: Part 1: Agave Bagasse as a Raw Material for Animal Feeding and Fiberboard Production. Bioresource Technology, 77, $25-32$. http://dx.doi.org/10.1016/S0960-8524(00)00137-1

[8] Iñiguez, C.G., Martínez, G.A., Flores, P.A. and Virgen, C.G. (2011) Utilización de subproductos de la industria tequilera. Parte 9. Monitoreo de la evolución del compostaje de dos fuentes distintas de bagazo de agave para la obtención de un substrato para jitomate. Revista Internacional de Contaminación Ambiental, 27, 47-59.

[9] Martínez, G.G.A., Iñiguez, C.G., Ortíz, H.Y.D., López, C.J.Y. and Bautista, C.A. (2013) Tiempos de apilado del bagazo del maguey mezcalero y su efecto en las propiedades del compost para sustrato de tomate. Revista Internacional de Contaminación Ambiental, 29, 209-216.

[10] Crespo, G.M.R., González, E.D.R., Rodríguez, M.R., Rendón, S.L.A., Del Real, L.J.I. and Torres, M.J.P. (2013) "Evaluación de la composta de bagazo de agave como componente de sustratos para producir plántulas de agave azul tequilero. Revista Mexicana de Ciencias Agrícolas, 4, 1161-1173.

[11] Rodríguez, G.L.B., Fernández, C.F.A., Iñiguez, C.G., Rodríguez, G.E., Rodríguez, D.E. and Arriaga, R.M.C. (2010) Utilización de bagazo de agave como sustrato para producción de plántulas de tomate. Sciencia-CUCBA, 12, 11-15.

[12] Rodríguez, M.R., Jiménez, J.F., Del Real, L.J.I., Salcedo, P.E., Zamora, J.F. and Iñiguez, C.G. (2013) Utilización de subproductos de la industria tequilera. Parte 11. Compostaje de bagazo de agave crudo y biosólidos provenientes de una planta de tratamiento de vinazas tequileras. Revista Internacional de Contaminación Ambiental, 29, 303-313.

[13] Iñiguez, C.G., Acosta, N., Martínez, L., Parra, J. and González, O. (2005) Utilización de subproductos de la industria tequilera. Parte 7. Compostaje de bagazo de agave y vinazas tequileras. Revista Internacional de Contaminación Ambiental, 21, 37-50.

[14] Iñiguez, C.G., Flores, S. and Martínez, L. (2003) Utilización de subproductos de la industria tequilera. Parte 5. Biodegradación de material de descarne de la industria de curtiduría. Revista Internacional de Contaminación Ambiental, 19, 83-91.

[15] Iñiguez, C.G.and Pilar, V. (2001) Utilización de subproductos de la industria tequilera. Parte 4. Biodegradación del intestino grueso de cerdos con bagazo de agave húmedo. Revista Internacional de Contaminación Ambiental, 17, 109-116

[16] Alonso, M.S. and Rigal, L. (1997) Caracterización y valoración del bagazo de Agave tequilana Weber de la industria del tequila. Revista Chapingo, Serie Horticultura, 3, 31-39. 